\title{
Enhancing ecosystem services through afforestation: How policy can help*
}

Luke E. Barry ${ }^{a}$, Richard T. Yao ${ }^{a}, *$, Duncan R. Harrison ${ }^{a}$, Upananda Herath Paragahawewa ${ }^{\mathrm{b}}$, David J. Pannell ${ }^{\mathrm{c}}$

${ }^{a}$ New Zealand Forest Research Institute Ltd. (trading as Scion), Private Bag 3020, Rotorua 3046, New Zealand

${ }^{\mathrm{b}}$ AgResearch Ruakura Research Centre, 10 Bisley Road, Hamilton 3214, New Zealand

${ }^{c}$ Centre for Environmental Economics and Policy (CEEP), The University of Western Australia (M089), 35 Stirling Highway, Crawley, WA 6009, Australia

\section{Abstract}

We employ an integrated spatial economic model to assess the net private and public benefits of converting marginal agricultural land into forest plantations (afforestation) in New Zealand. For numerous locations, we conduct policy analysis considering the magnitudes of net private and public benefits of land-use changes to determine whether a policy response is justified and, if so, to identify the appropriate policy instruments to encourage adoption of afforestation. Net private benefit is commonly negative, so much so, that in most cases no policy response is justified. However, in certain cases, net private benefits are slightly negative and public benefits are significantly positive justifying the use of positive incentives as the most appropriate policy instrument to encourage afforestation in New Zealand. The most commonly used policy instruments for afforestation in New Zealand, extension and awareness training, are found to be appropriate in only a minority of situations.

Keywords: ecosystem services; afforestation; avoided erosion; marginal land

\section{Introduction}

New Zealand's land cover has undergone dramatic change over the past century. Much of the original native vegetation has been removed to make way for pastoral agriculture, which has led to increased soil erosion, especially in hilly areas (Hicks, et al., 2000; Jansson, 1988; Rhodes, 2001). The

\footnotetext{
* Barry, L.E., Yao, R.T., Harrison, D.R., Paragahawewa, U.H. and Pannell, D.J. (2014). Enhancing ecosystem services through afforestation: How policy can help, Land Use Policy 39, 135-145. http://dx.doi.org/10.1016/j.landusepol.2014.03.012
} 
demand for agricultural activities in New Zealand is likely to increase as the country's population is expected to increase to approximately six million by 2061 from the current level of 4.4 million (Statistics New Zealand, 2011) along with a continued growth in export markets forecasted across the dairy, meat and wool industries (MPI, 2012). This extra pressure for agricultural land means that the country's soils may deteriorate further. Appropriate policy intervention could reduce this deterioration. It has been highlighted in the New Zealand context that the use of science to inform such policy intervention should focus on the appropriate interpretation of data, which considers knowns and unknowns while being free from a particular political agenda (Gluckman, 2011). Although the approach, which follows, capitalises on data from a forestry perspective to inform land use policy, the process by which this data is brought together caters to the aforementioned issues for informing policy intervention.

The Millennium Ecosystem Assessment (2005) (MEA) highlighted forests, including planted forests, as providing the greatest number of ecosystem services across all ten key ecosystems examined (cultivated, dryland, forest, urban, inland water, coastal, marine, polar, mountain and island). Ecosystem services are categorised into four broad groups: cultural, regulating, provisioning, and supporting services (De Groot, et al., 2002; Dominati, et al., 2010; Millennium Ecosystem Assessment, 2005). For the New Zealand planted-forest ecosystem, cultural services include aesthetic experience, native species conservation, and recreation. Main regulatory services include flood mitigation, water quality improvement, avoided erosion and carbon sequestration (Dymond, et al., 2012). Provision of wood and fibre, and raw materials are the main provisioning services, while supporting services are the biological, chemical and physical processes which underpin the provision of the other services.

Planted forests in New Zealand are usually a monoculture of the exotic species Pinus radiata D.Don (radiata pine). A number of ecosystem services from these planted forests can be valued economically and some examples are given below. Timber production, a provisioning service, represents a significant part of New Zealand's economy. Logs were the fourth largest export in 2012, contributing over NZ\$1.3billion in export earnings (Statistics New Zealand, 2012). Another ecosystem service from New Zealand forestry is carbon sequestration. New Zealand is the only country to include forestry in its Emissions Trading Scheme (ETS), which began in January 2008. The ETS provides tradable New Zealand Units (NZUs) to forest growers for sequestered carbon (MAF, 2011a). Reduced soil erosion is another important ecosystem service from planted forests. The cost of erosion in New Zealand has been estimated at approximately NZD\$200 million annually (Dymond, et al., 2012; Krausse, et al., 2001). Finally, New Zealand has also been considered as one of the top 25 biodiversity hotspots globally due to its exceptional levels of endemism and high levels of habitat 
loss (Myers, et al., 2000). Planted forests provide habitats to at least 118 threatened native species, which include iconic (e.g., brown kiwi, bush falcon) and non-iconic (e.g., native vascular plants) species (Brockerhoff, et al., 2008; Pawson, et al., 2010; Seaton, et al., 2009).

Our goal is to build on a previous study (Dymond et al. 2011) that compared various trade-offs among ecosystem services across New Zealand. Dymond et al. (2011) focused on ecosystem services such as water availability, soil erosion, and carbon sequestration, whereas we focus on timber production, carbon sequestration, avoided erosion, and biodiversity provision. We also conduct a policy analysis that takes into consideration both the net public and private benefits of afforestation using a framework developed by Pannell $(2008 ; 2009)$. This framework has been applied in different studies to identify policy mechanisms and encourage land-use change (Cary, et al., 2011; ParraLópez, et al., 2009). However, as far as we know, the framework has not been employed to identify relevant policy instruments for land-use changes associated with perennial crops such as forestry.

Much literature to date has recognised the inherently spatial nature of such ecosystem services (Bateman, et al., 2011; Dymond, et al., 2012; Wätzold, et al., 2005) and Maes et al., (2012) (Maes, et al., 2012) have highlighted the reliance of policy on spatially explicit information describing ecosystem services. We extend this concept by developing a spatial economic model that has particular utility for policymakers because it:

- $\quad$ accounts for the value of the final ecosystem service benefits (Fisher, et al., 2008);

- defines the ecosystem services to be valued according to relevant temporal and spatial scales (Fu, et al., 2011);

- $\quad$ uses a safe minimum-standard approach to avoid introducing uncertainty from potentially overlapping valuation methods that are typically used for biodiversity valuation (e.g., choice modelling, contingent valuation) (Bateman, et al., 2011);

- differentiates between public and private benefits (Pannell, 2008) to avoid potential doublecounting of benefits across stakeholders of ecosystem-service benefits. The problem of double counting has been highlighted in similar studies in the past (Dominati, et al., 2010; Jones, et al., 2008) particularly in valuing benefits of avoided soil erosion. 


\section{$2 \quad$ Methodology}

\subsection{Spatial Economic Modelling of Ecosystem Services}

This study focuses on areas of New Zealand that would be suitable for afforestation, henceforth known as future forests (Watt, et al., 2010). These are areas considered to have relatively low economic value for agriculture and slight to extreme erosion severity. Biodiversity is likely to increase if these areas are forested compared to their current use for pastoral agriculture. The various forest scenarios modelled here are based on a structural (framing) regime (thinned to 600 tree stems ha ${ }^{-1}$ from initial planting of 900 tree stems $\left.h^{-1}\right)$. The rotation length modelled is 28 years as this represents the most common rotation length practice in New Zealand.

Assessment of ecosystem services in combination with economic analyses can be grouped into two types: one focuses on 'sustainable analyses' of current land use and the other on 'programme evaluation'. 'Sustainability analysis' provides an investigation of changes up to the present day to assess the sustainable path of previous strategies while 'programme evaluation' provides a forwardlooking assessment of potential sustainability policies (Bateman, et al., 2011). We used a 'programme evaluation' of afforestation across marginal agricultural land suitable for forestry in New Zealand to identify, spatially, those policies that can efficiently enhance ecosystem services provision.

\subsection{Private Net Benefits}

The term 'private net benefits' refers to the benefits, minus the costs, of a land-use change that accrue to the private landowner (Pannell, 2008). This term is calculated as the discounted sum of the costs and benefits (Net Present Value) to the private individual from afforestation, and includes the opportunity cost of land-use change. For a consistent measure of opportunity cost across all future forests, land-value data is used from a property valuation specialist (PropertylQ, 2008). In New Zealand, land is typically valued by its "highest and best use" (New Zealand Institute of Chartered Accountants, 2004). The Land Expectation Value (LEV) is the net present value (NPV) of an investment in an even-aged stand from the time of planting, throughout infinite rotations of the same management regime (Faustmann, 1995). If the LEV is greater than the upfront cost of purchasing the land (i.e. the land value) then afforestation would be a rational investment from a private commercial perspective. Hence, if the land was already owned by the investor and the LEV was positive then forestry would be a viable option. This approach can also be applied to third-party investments, where the purchase of land represents an upfront investment in forestry cash flows. 
Table 1 lists the spatial revenues and costs calculated in the model. We also considered the transaction and learning costs of land-use changes to forestry in policy analysis as per Pannell (2008); see Appendix D for detailed assumptions.

[Table 1 should be about here]

We use the ArcGIS 10 software (ESRI, 2010) to identify meshblocks ${ }^{1}$ (the smallest geographic unit for which statistical data is collected) that contained future forest areas. Each meshblock has a corresponding code; this code was sent to PropertylQ who identified property data relating to each meshblock. The associated land values are summed then divided by the area of the meshblock to estimate a per-hectare value for each meshblock. This value per hectare is then divided by 16 to estimate a value per 625 square metres, the same scale as all GIS surfaces used in the model. This data is used to generate a raster layer in ArcGIS 10 which is used in the calculation of the private net benefit.

\subsubsection{Provisioning Service: Timber}

Comprehensive fine-resolution terrain datasets for New Zealand have been produced and are described in (Palmer, et al., 2009a; Palmer, Watt, et al., 2009b). These datasets are suitable for the modelling of planted forestry costs and productivities because they are key indicators of impedances, or physical barriers, which impact on forestry processes. We assess costs by running the model for known forests and using expert knowledge to adjust impedance values against reasonable real world costs (Table 1). Major data sets required for the impedance variation of forestry costs are slope, rainfall, erosion classes, river classes, and the identification of lakes and wetlands. The New Zealand Land-Use Capability classes (Lynn, et al., 2009) and the New Zealand Land Cover Database 2 (AsureQuality, 2009; Thompson, et al., 2003) represent the impedances for which forests costs are adjusted.

The 300 Index is a model used for determining productivity of radiata pine in New Zealand (Kimberley, et al., 2005). This model has been combined with another model for determining Site Index to generate a series of productivity surfaces across New Zealand (Palmer, et al., 2009a; Palmer, et al., 2010). These surfaces are used to estimate predicted log grade volumes using regression analysis ${ }^{2}$. Logs of a number of different grades may be obtained from a single tree. More intensive silviculture, possibly including pruning, may provide a higher proportion of higher value grades which, in turn, produce higher value wood products.

For roading costs, impedance surfaces are generated using costpath analysis that provides a realistic cost of travelling across the digital landscape within the GIS environment. These surfaces are used to 
estimate: where new forest roads should be constructed; and the likely costs associated with road construction. If a future forest was not already located on the current New Zealand road network then it required extra construction of roads to the forest (external road construction). The 'cost of transport' analysis is then used to calculate the least-cost distance to the nearest mill or port in New Zealand. In this analysis, we do not differentiate between export logs and those for domestic consumption due to data insufficiency.

For each forest, the NPV of forestry in perpetuity is determined using discounted cash flow analysis, with the goal to estimate the LEV (Bettinger, et al., 2008); see also section 2.2. Prices for timber are based on the average price for each grade over the 16 quarters (March 2008 - December 2011, inclusive) taken from Ministry of Agriculture and Forestry (MAF) ${ }^{3}$ indicative domestic Pinus radiata log prices (MAF, 2012). Because this model does not differentiate between export logs and those for domestic consumption, domestic log prices were used. Export logs have commanded a higher price for similar log grades in recent years (MAF, 2012) and consequently the use of domestic prices is in keeping with the conservative nature of this research.

\subsubsection{Regulating Service: Carbon Sequestration}

Under the ETS, landowners are able to receive revenue for the carbon sequestered in their forests, which makes carbon sequestration a market benefit for the private landowner. Credits (NZUs) earned during the growth of the forest are surrendered at the time of harvest. Usually a small amount of credits would be retained due to the below-ground biomass left in the forest but this would have little economic effect. The level of carbon sequestration is calculated from the same surface used to determine timber productivity (300 Index) combined with the C-Change carbon model (Beets, et al., 2011, 2012).

Carbon credits provide revenue during growth followed by a liability at harvest (Manley, 2012). The price for an NZU has been dropping steadily since its inception, a price of NZ\$4 is used in this analysis as the price as of 27 September 2013 was about NZ\$4.40 per NZU (OM Financial Ltd.,

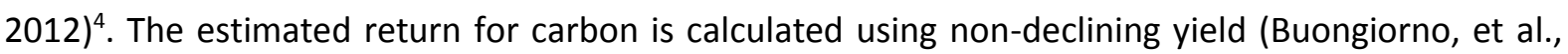
2003) so the revenue may be slightly underestimated (see Appendix B for calculations).

\subsection{Public Net Benefits}

Public net benefits refer to the benefits minus the costs to everyone except the private land owner from a land-use change, in this case afforestation. It excludes the cost of any intervention undertaken by a public body to encourage land-use change (Pannell, 2008). 


\subsubsection{Regulating Service: Avoided Erosion}

Avoided erosion is measured as the change in sedimentation levels from afforestation and is estimated using the New Zealand Empirical Erosion Model (NZEEM) (Dymond, et al., 2010). The NZEEM calculates the amounts of sediment generated under the current land use or woody vegetation in tonnes of sediment per square kilometre per year. The model assumes full canopy cover and therefore maximum soil protection when land use is changed from pasture to woody vegetation. However, sedimentation from forestry may be the same or worse than other land uses during harvesting and early establishment periods (Fahey, et al., 2006; Marden, et al., 2005; Marden, et al., 1993). Therefore, a range of estimated values of sedimentation level with forest age are used to further estimate the sedimentation avoided over an entire single forest rotation compared to the current land cover for the same time period (Fahey, et al., 2006). These estimates relate to a paired catchment study of sediment flows between pasture and forestry over time, whereby harvesting and early establishment can increase sedimentation relative to pasture from sidecast (area where movement of excavated material downslope occurs during road and landing construction), old road lines, shallow landslides and channel-bed scouring (Fransen, 1998).

The economic data collected for avoided sedimentation consist of avoided expenditure costs. They were estimated from discussions with regional and city councils in New Zealand. They account for avoided flood damage (NZ\$ 0.90/tonne) and avoided water-treatment costs to consumptive water (NZ\$ 5.60/tonne). Therefore, an estimate of NZ\$6.50/tonne is applied to the NZEEM results to determine the net public benefit as a result of afforestation. The value of avoided sedimentation is discounted into perpetuity for a consistent economic comparison between public and private benefits (see Appendix 5.C for calculations).

Pimentel, et al. (1995) estimated the off-site cost of soil erosion to be approximately US\$3/tonne. Converting to New Zealand dollars for this period (1995) and adjusting for inflation, this figure was approximately NZ\$6.60/tonne in 2012 (OANDA, 2012; Reserve Bank of New Zealand, 2012). In another study, Dymond et al. (2012) used a top-down approach to estimate the value per tonne, whereby they considered Krausse et al.'s (2001) estimate of NZ\$127million for the cost of soil erosion annually in New Zealand and translated that into current dollars (ca. NZ\$200m) and divided this by the annual amount of soil exported to the sea each year. This equates to a cost of approximately NZ\$1/tonne of sediment eroded. Neither estimate can claim to be accurate across space. For example, Krausse (2001) points out that his estimate does not account for a number of costs related to soil erosion (e.g., recreational damage) and does not deal very well with double 
counting. However, recent evidence from a case study in New Zealand suggests that the social value of soil erosion may be larger than the avoided expenditure cost (Porou, et al., 2012).

\subsubsection{Cultural: Biodiversity}

Environmental valuation techniques can provide useful evidence to support policies by quantifying the economic values (including environmental and social values) associated with land-use change. Two such techniques are: 'stated preference' and 'revealed preferences' methods (Champ, et al., 2003). Pearce (2001) argues that a robust estimation of the economic value of biodiversity conservation (or enhancement) can serve as a fundamental step towards conservation since "the pressures to reduce biodiversity are so large that the chances that we will introduce incentives without demonstrating the economic value of biodiversity are much less than if we do engage in valuation" (Pearce, (2001). Failure to account for the value of non-market goods (e.g., conservation of endangered native species) in decision making, results in less efficient resource allocation, with negative consequences for social well-being (Quine, et al., 2011).

Yao and Kaval (2010) employed a stated preference technique called "contingent valuation" to estimate the value to New Zealanders of a proposed program to improve the provision of habitats for native species on private and public lands. Using a sample of more than 700 respondents across New Zealand, they found a typical respondent would pay about NZ\$42 per year for a proposed program on planting additional native trees on private lands. The program aims to provide habitats to key native species (e.g., tui bird, green gecko and giant kokopu fish). That study has been extended by Yao (2012) using a "choice modelling" technique to estimate the value that a sample of more than 200 respondents would place on increasing the abundance of threatened native species (e.g., brown kiwi, bush falcon, kakabeak) that are found in planted forests. In this instance, a typical respondent would pay approximately NZ\$50 per year for a proposed programme that would increase the opportunity to see or hear those threatened species in planted forests (e.g., increasing the sighting of a bush falcon from "1-out-of-8-drives" to "5-out-of-8-drives" in planted forests in the Central North Island region). These two studies provide evidence that many New Zealanders would be willing to financially support programmes that would enhance the provision of habitats for native species on private land and even in planted forests.

Simply changing the use of land from pastoral agriculture to planted forests cannot alone guarantee increased abundance of indigenous species. Although planted forests provide a habitat more suitable to the species valued above (Pawson, et al., 2010; Yao, 2012), the time required for a population to establish to the levels valued in the above stated-preference studies is unknown. Furthermore, because a population of a species could not be guaranteed simply from afforestation, 
an additional payment would be required to ensure that landowners take the necessary steps to establish a population. A payment for ecosystem services is "additional" when it encourages a change in behaviour that would not have occurred otherwise (Engel, et al., 2008). We are interested in policies to encourage landowners away from the status quo to enhance ecosystem service provision and so using these values for biodiversity would present an unrealistic alternative scenario.

In an evaluation of land-use options using modelling, there is inevitably uncertainty about the outcomes and consequences. In particular, there is a possibility of adverse consequences. Consistent with a safe-minimum-standards approach (Bateman, et al., 2011) we specify a set of criteria for excluding such situations from consideration for afforestation (Appendix A). For example, we remove sub-categories for fernland, manuka and or kanuka, matagouri, broadleaved indigenous hardwoods, sub alpine shrubland, and grey scrub from scrub and shrubland and tussock from grassland, to minimise further ecosystem loss.

\subsection{The Policy Analysis Framework}

We employ the Public:Private Benefits Framework (PPBF) (Pannell, 2008) to assess the appropriateness (from an efficiency perspective) of policy instruments aimed at encouraging changes in land use from marginal agricultural activities to forestry. The basic principle of the PPBF is to determine the magnitudes of both private and public net benefits of alternative land uses compared to the current land use. By construction, the private and public net benefits of current land use are set at zero, i.e. the zero-zero point of the framework represents the current land-use activity (Figure 1). The framework identifies the appropriate class of policy mechanism for a particular case depending on the magnitude of net private and public benefits, relative to current land use. Figure 1 shows a simple version of the framework that omits transaction costs and time lags involved in behaviour change. When a change in land use results in increases in both private and public net benefits then suasive or information-related policy instruments are recommended. Such instruments include education, technology transfer and communication (collectively known as Extension) (Area A, Figure 1). When the net public benefit of a land-use change is large and positive but the net private benefit is slightly negative (not far away from the origin - Area B) then positive incentives may be appropriate policy instruments. However, when the public net benefit is positive but the private net benefit is considerably negative (Area $\mathrm{C}$ ), researchers should reconsider developing improved technology to enhance the private net returns from land-use changes. If that option is judged not to provide good value for money, the remaining option is to decide to take no action, on the basis that there are no options for which the benefits outweigh the costs.

[Figure 1 should be about here] 
In our assessment of policy instruments to encourage changes in land use from marginal agriculture to forestry, we generate results for three different hurdle benefits: cost ratios: 1.0, 2.0 and 3.0. If the BCR for an intervention does not at least equal the hurdle level, the selected response is "no action". Because forestry is a perennial activity, we estimate the private and public net benefits as NPVs. However, we employ different real discount rates for the net private benefits (8\%) and net public benefits (4\%). It is reasonable to use different discount rates in this case because the behaviour change by the private sector would depend on their own discount rate, not the public rate. The level of payment required would depend on the level of compensation people felt they needed, which, in turn, would depend on the private discount rate. However, the payment itself would be a public payment, making it valid to compare it with the public benefits.

\section{$3 \quad$ Results and Discussion}

The analysis calculates the private and public net benefits from converting marginal agricultural land to forestry for 2.5 million ha across New Zealand. Results are summarised for 16 regions in Table 2. In all 16 regions, private net benefits have negative mean and median values, indicating that most future forest areas would not be commercially viable for afforestation unless they receive sufficient financial support for ecosystem services they provide. The mean public net benefit is larger than the mean private net cost, in only one region, Gisborne, implying that only in that region would substantial areas be viable for afforestation even after allowing for payments for ecosystem services.

[Table 2 should be about here]

Due to spatial heterogeneity, the means and medians in Table 2 do not tell the whole story. Figure 2 shows that there are areas across New Zealand that have positive private net benefits from afforestation. These areas with positive private net benefits or low private costs might be prime targets for policy intervention.

[Figure 2 should be about here]

For each area, the Public:Private Benefits Framework was applied, using ' 3 ' as the hurdle Benefit: Cost Ratio (In this case of this research it is a public benefit to a private cost). Figure 3 indicates whether each area passes this hurdle, accounting for learning costs, transaction costs and time lags until adoption.

Across New Zealand, the optimal response for most of the areas analysed is "No action". However, there are many areas where either extension or positive incentives is a favourable policy response, resulting in BCRs of at least three. This is particularly the case in regions that have high erosion rates, 
such as Gisborne. Each map has a more detailed close up of the Gisborne region to illustrate the variation at a finer scale.

[Figure 3 should be about here]

The Gisborne region is where the East Coast Forestry Project (ECFP) (MAF, 2011b) ${ }^{5}$ took place. Our analysis not only provides evidence to support the investment in this project, but it could also help to identify areas where the policy may be more finely targeted. For example, the total value of avoided erosion into perpetuity across all the future forests ( 2.47 million hectares) is estimated at NZ\$3.6 billion. However, focusing on the region with the highest level of avoided erosion per hectare from afforestation (Gisborne), accounts for 45 percent of this value, while accounting for only seven percent of the total future forest area. Figure 4 provides a visualisation of the future forests in this study using the policy framework for a subsection of future forests occurring within NZ\$2000/ha to $\mathrm{NZ \$ O} /$ ha in the North Island of New Zealand with a BCR of three.

[Figure 4 should be about here]

This mapping process used data from the AgriBase ${ }^{\mathrm{TM}}$ enhanced Land Cover Database 2 (LCDB2) (AsureQuality, 2009), which represents the land cover type for the period Summer 1996/97 and Summer 2001/02. Since 1992, the ECFP has provided grants to landowners to plant more forests on erosion-prone land. The current study extends the range of possible incentives by providing a highlevel assessment of a variety of policies that could be used to encourage afforestation. Although a national-scale analysis highlights areas and policies to improve sustainable land use, further investigation at the community level would be required before decisions about target areas are made. The socioeconomic characteristics of the community along with their willingness to engage will affect the success of any policies suggested (Collins, et al., 2007). Recent evidence from the East Coast of New Zealand identified some community members as being unable to participate in the ECFP because erosion results in them having less access to credit (Porou, et al., 2012).

The hurdle BCR that should be used depends on the availability of funds in a program: the lower the budget, the higher the BCR an investment needs to achieve to be part of the elite set of investments. Table 3 shows how results are affected by variations in the hurdle $B C R$, accounting for transaction costs, learning costs and lags to adoption. For instance, across both islands in New Zealand, as the Benefit Cost Ratio is increased the potential area for extension and positive incentives are reduced. The remaining areas, as we move from $\mathrm{BCR} 1$ to $\mathrm{BCR} 3$, therefore have a higher priority for public investment.

[Table 3 should be about here] 
Table 3 shows that relatively few areas exist for which extension would be recommended: less than 10,000 ha in all scenarios. This was expected given that the average annual area of new plantings over the last 5 years (up to 2011) is approximately 5,300ha (MPI, 2012). However there are areas where extension may be all that is necessary to encourage some afforestation, while there are certainly many more areas where positive incentives would be recommended. New Zealand generally relies on markets to allocate resources and determine production processes to supply goods and services (Collins, et al., 2007). However, markets are not efficient for providing goods that have characteristics that cause market failure, such as externalities associated with public goods (Randall, 1983). In our analysis, we find that, providing positive incentive payments for conversion of marginal farm land to forestry would generate BCRs of at least 3 over approximately 100,000 ha. The vast majority of these areas occur on New Zealand's North Island. These payments would succeed by making privately unprofitable but socially desirable practices become profitable to individual land owners (Engel, et al. (2008).

Some simplifying assumptions used in the analysis should be acknowledged. Carbon value is estimated as a non-declining yield and the value of each tonne of avoided soil erosion (NZ\$/tonne) is constant across space and therefore only varies according to the volume of erosion. Not all ecosystem services are accounted for and valued in this study. This may have varying effects on the results, for example Dymond et al. (2012) identified water availability as an ecosystem service with a public net cost given a switch of land use from agriculture to forestry. In contrast, evidence suggests that recreation would result in a public net benefit from a transition to forestry (Dhakal et al., 2012; UK National Ecosystem Assessment, 2011; Millennium Ecosystem Assessment, 2005). Therefore, results should be treated as indicative, rather than definitive.

On the other hand, we attempted to reduce uncertainty in ecosystem valuation by: focusing on detailed spatial valuation of private net benefits; restricting potential land-use change to areas where evidence suggests that further non-market valuation would realise an improved public net benefit; and using a relatively conservative (i.e. high) ratio between public and private net benefits, as proposed in Pannell (2008). Therefore, this study helps to identify key areas where afforestation should be encouraged in New Zealand, focusing on the relevant policies which would encourage this land-use change at least cost to society. More detailed local-scale analysis would assist to identify areas where afforestation should be encouraged (Collins, et al., 2007).

Finally, this paper does not attempt to prescribe 'Technology Development' as a policy option. There may be areas in New Zealand where 'No Action' is prescribed but 'Technology Development', such as genetic modification for improved tree growth, may result in these areas becoming privately profitable or reducing the private net cost to a point where 'Positive Incentives' may be justified. 
Technology development may also improve the public net benefit, for example, investment in improved harvesting techniques may reduce soil disturbance. Technology development may therefore be justified across many areas of New Zealand, however, assessing areas for technology development requires consideration of the likelihood of delivery of a technology, the time lag until delivery, and the cost of research and development (Pannell, 2008), which are outside the scope of this paper.

\section{Conclusion}

Our analyses indicate that the private net benefit of the proposed afforestation schemes is negative in almost all cases. Therefore land-use change would tend not to occur without government intervention to provide a positive incentive. The public net benefit of conversion is heterogeneous. In most areas, it is less than the private net cost, but in certain highly erosion-prone areas, it is greater. If we had considered all of the potential ecosystem services from land use change (e.g., recreation), a greater area for which benefits exceed costs by the required amount may have been identified. The study indicates that, even with a conservative BCR of three, there are over 100,000ha across New Zealand for which positive incentives would be justified to encourage socially desirable practices. Across New Zealand, the optimal response for most of the areas analysed is "No action".

Gisborne is the region with the largest land areas where incentivising afforestation would be rational. As the region has the highest soil erosion rate in the country, it would receive the greatest benefit from avoided erosion following afforestation. It is recommended that afforestation should continue to be strongly encouraged or incentivised in this region. Perhaps an improved and more flexible scheme that amalgamates existing afforestation programmes should be developed.

This study has contributed to addressing the long-standing issue of 'double counting' in estimating the benefits of ecosystem services. In particular, the net benefits of avoided soil erosion are recognised by: grouping the net benefit of avoided soil erosion into private and public benefits, accounting for only final ecosystem service benefits, using a safe minimum standards approach to avoid overlapping valuation approaches, and defining the relevant temporal and spatial scale of final ecosystem service benefits. This approach has also allowed us to identify the most efficient policy instruments to encourage afforestation in marginal agricultural lands in different areas of New Zealand.

The literature surrounding the ecosystems services approach is growing rapidly (Braat, et al., 2012; Fisher, et al., 2009), which brings new solutions and new problems. However, people undertaking an ecosystem-service valuation of this scale should not be deterred by the level of complexity 
associated with the ecosystem service approach. We have shown that a national-scale analysis can provide meaningful information for strategic regional and national decision making.

Burton, et al. (2011) indicate that private net benefit is impacted not only by financial gains or losses (economic capital) of land-use changes, but also by losing or gaining other forms of capital, such as social capital, due to land-use changes. Assessing this type of capital may be needed for understanding and determining learning costs and the lag to adoption for policy measures for the New Zealand context. Estimation in a New Zealand context would be advisable for future studies to make effective policy measures to encourage adoption of future forest schemes in New Zealand. 


\section{$5 \quad$ Appendices}

\section{A Future Forest Criteria}

- The sub-categories from $1^{\text {st }}$ order classes grassland, and scrub and shrubland, from the AgriBase $^{\mathrm{TM}}$ enhanced Land Cover Database 2 (LCDB2) (AsureQuality, 2009) were selected.

- Removal of sub-categories for fernland, manuka and or kanuka, matagouri, broadleaved indigenous hardwoods, sub alpine shrubland, and grey scrub from scrub and shrubland and tussock from grassland, to minimise further ecosystem loss.

- $\quad$ Shrubland classes were excluded as they are considered native carbon sinks.

- Land with the potential for high returns was excluded, this was everything except beef, deer, grazing other peoples' stock, not farmed-idle, sheep, mixed sheep and beef, and unspecified for low producing grassland and beef for high producing grassland.

- $\quad$ Land-use capability (LUC) classes were used to exclude arable and slightly limited non-arable land classes and to differentiate between the three scenarios on the basis of erosion severity (Lynn, et al., 2009).

- Using a $500 \mathrm{~m}$ resolution normalised climate surface (NIWA, 2009), areas with annual temperature below $7.9{ }^{\circ} \mathrm{C}$ were excluded, as productivity for Pinus radiata is very low below this threshold.

- Areas were limited to a predicted 300 Index of $5 \mathrm{~m}^{3} \mathrm{ha}^{-1} \mathrm{yr}^{-1}$ and a site index of $13.5 \mathrm{~m}$ (Palmer, Hock, et al., 2009b) as productivity values have not been recorded below these parameters.

- Grassland and shrubland areas that have unique biodiversity value and would not naturally support trees were excluded using a number of predicted vegetation classes (McGlone, et al., 2004).

- Department of Conservation estate and current plantations were also excluded.

\section{B Carbon Accounting}

Carbon revenue is an annuity and it was assumed that the forest is managed to provide a nondeclining yield (Maclaren, 2000), based on volume control (Buongiorno, et al., 2003). This non declining yield is defined as:

$$
\mathrm{NDY}=\overline{\mathrm{C}}_{/ \mathrm{T}}
$$


Where $\overline{\mathrm{C}}$ is the average expected carbon stock $\left(\mathrm{t} \mathrm{ha}^{-1}\right)$, assumed to be half the total carbon stock at rotation end $\left(0.5 \mathrm{C}_{\mathrm{F}}\right)$, where $\mathrm{C}_{\mathrm{F}}$ is the total carbon stock at rotation end. The revenues from carbon are received as carbon credits or New Zealand Units (NZUs). One NZU is equivalent to one tonne of carbon dioxide $\left(\mathrm{CO}_{2}\right)(\mathrm{MAF}, 2011 \mathrm{a})$. The productivity surfaces for carbon measured the total carbon sequestered in tonnes/ha. This was then converted to $\mathrm{CO}_{2}$ equivalents by using the mass ratio of carbon to $\mathrm{CO}_{2}$ (1/3.67) (United States Environmental Protection Agency, 2005). The annual carbon revenue $(A R)$ is then the non-declining yield times the price of carbon $\left(\mathrm{P}_{\mathrm{CO} 2}\right)$ :

$$
A R=N D Y\left(P_{\mathrm{CO} 2}\right)
$$

The present value calculation for the carbon revenue annuity using a rotation length of $T$ years is therefore calculated as:

$$
\mathrm{PV}_{\mathrm{AR}}=\mathrm{AR} \quad\left(\frac{1}{r_{p}}-\frac{1}{r_{p}\left(1+r_{p}\right)^{T}}\right)
$$

While the annual carbon cost $\left(\mathrm{PV}_{\mathrm{AC}}\right)$ for monitoring and administration of $\$ 60 \mathrm{ha}^{-1}$ (Turner, et al., 2008 ) is an annuity cost calculated in the same way, such that:

$$
N P V=P V_{A R}-P V_{A C}
$$

Generally using the LEV assumes that costs and revenues are identical in all rotations, however to provide a more realistic scenario, it should be acknowledged that the first rotation (F1) would incur greater costs for road and landing construction than subsequent rotations (F2). Therefore, following consultation with a roading engineer subsequent internal road and landing costs were estimated to cost about forty-five percent of the initial construction costs. Hence the LEV is adapted from Bettinger et al. (2008) to be:

$$
L E V_{F}=N P V_{F 1}+\left(\frac{N P V_{F_{2}}}{\left(1+r_{p}\right)^{T}-1}\right)
$$

Whereby NPV $V_{F 1}$ represents the net present value from the first rotation and NPV $F$ represent the net present value of subsequent forest rotations which is then discounted into perpetuity with private discount rate $r_{p}$ and rotation length $\mathrm{T}^{6}$. 


\section{Soil Erosion Accounting}

The value of avoided erosion is calculated as,

$$
N P V_{i}=\sum_{t=0}^{T} \frac{\left(s_{p i}-s_{f i}\right)\left(s_{t}\right)\left(P_{\ell}\right)}{\left(1+r_{s}\right)^{t}}
$$

where, $s_{\mathrm{pi}}$ is the rescaled sedimentation coefficient from the NZEEM measuring tonnes of sediment lost for land use $p$ (pasture, $f$ for forest) and area i. $P_{e}$ is the estimated price per tonne of sediment lost, $\mathrm{S}_{\mathrm{t}}$ is a vector of the sedimentation ratio of pasture to forestry at time $t$ for rotation length $\mathrm{T}$, while $r_{s}$ is the social discount rate. This is then calculated into perpetuity as the Land Expectation Value (LEV):

$$
L E V_{i}=N P V_{i}\left(1+\frac{1}{\left(1+r_{s}\right)^{T}-1}\right)
$$

\begin{tabular}{|c|c|c|}
\hline & Extension & $\begin{array}{l}\text { Positive } \\
\text { Incentive }\end{array}$ \\
\hline Information cost of adoption (Learning Cost, Cl) & $\$ 10.00$ & $\$ 10.00$ \\
\hline Transaction costs of the program $(\mathrm{Ct})$ & $\$ 2.50$ & $\$ 2.50$ \\
\hline Parameter on adoption curve (k) & 50.00 & 50.00 \\
\hline Discount rate $(r)$ & 0.08 & 0.08 \\
\hline Benefit Cost Ratio (BCR) & 3.00 & 3.00 \\
\hline Shift in adoption due to extension (Alpha) & 3.00 & 3.00 \\
\hline
\end{tabular}

\section{Policy Assumptions}

\section{Acknowledgements}

The research greatly benefited from the contributions of Peter Hall, Mark Kimberley, David Palmer, Peter Clinton and Kit Richards. We thank participants at the New Zealand Agricultural and Resource 
Economics Conference 2012 for useful comments during the oral presentation. We also thank Ruth Falshaw for editorial assistance. We thank Future Forests Research Ltd. and Scion for funding this study.

\section{References}

AsureQuality. Retrieved 21 July 2012 http://www.asurequality.com/geospatial-services/agribasederived-products.cfm

Bateman, I., Mace, G., Fezzi, C., Atkinson, G., \& Turner, K. 2011. Economic Analysis for Ecosystem Service Assessments. Environ. Resour. Econ. 48, 177-218. doi:10.1007/s10640-010-9418-x

Beets, P. N., Brandon, A. M., Goulding, C. J., Kimberley, M. O., Paul, T. S. H., \& Searles, N. 2011. The inventory of carbon stock in New Zealand's post-1989 planted forest for reporting under the Kyoto protocol. For. Ecol. Manage. 262, 1119-1130.

Beets, P. N., Brandon, A. M., Goulding, C. J., Kimberley, M. O., Paul, T. S. H., \& Searles, N. 2012. The national inventory of carbon stock in New Zealand pre-1990 planted forest using LiDAR incomplete-transect approach. For. Ecol. Manage. 280, 187-197.

Bettinger, P., Boston, K., Siry, J. P., \& Grebner, D. J. 2008. Forest management and planning. Academic Press, New York.

Braat, L. C., \& de Groot, R. 2012. The ecosystem services agenda: Bridging the worlds of natural science and economics, conservation and development, and public and private policy. Ecosyst. Serv. 1, 4-15. doi:10.1016/j.ecoser.2012.07.011

Brockerhoff, E. G., Jactel, H., Parrotta, J. A., Quine, C. P., \& Sayer, J. 2008. Plantation forests and biodiversity: Oxymoron or opportunity? Biodivers. Conserv. 17, 925-951.

Buongiorno, J., \& Gilles, J. K. 2003. Decision methods for forest resource management. Academic Press, San Diego.

Burton, R. J. F., \& Paragahawewa, U. 2011. Creating culturally sustainable agri-environmental schemes. J. Rural Stud. 27, 95-104.

Cary, J., \& Roberts, A. 2011. The limitations of environmental management systems in Australian agriculture. J. Environ. Manage. 92, 878-885. doi: http://dx.doi.org/10.1016/i.jenvman.2010.10.055

Champ, P. A., Boyle, K. J., \& Brown, T. C. 2003. A primer on nonmarket valuation. Kluwer Academic Publishers, Dordrecht, The Netherlands. 
Collins, D., \& Whitten, S. 2007. Use of market based instruments by Catchment Management Authorities in NSW to achieve landscape scale change. NSW CMA Chairs' Council, BDA Group and CSIRO Sustainable Ecosystems.

De Groot, R. S., Wilson, M. A., \& Boumans, R. M. J. 2002. A typology for the classification, description and valuation of ecosystem functions, goods and services. Ecolog. Econ. 41, 393-408.

Dhakal, B., Yao, R. T., Turner, J. A., \& Barnard, T. 2012. Recreational users' willingness to pay and preferences for changes in planted forest features. Forest Policy and Economics, 17, 34-44.

Dominati, E., Patterson, M., \& Mackay, A. 2010. A framework for classifying and quantifying the natural capital and ecosystem services of soils. Ecolog. Econ. 69, 1858-1868.

Dymond, J. R., Ausseil, A.-G., Ekanayake, J., \& Kirschbaum, M. U. F. 2012. Tradeoffs between soil, water, and carbon - A national scale analysis from New Zealand. J. Environ. Manage. 95, 124131.

Dymond, J. R., Betts, H. D., \& Schierlitz, C. S. 2010. An erosion model for evaluating regional land-use scenarios. Environ. Model. Software 25, 289-298.

Engel, S., Pagiola, S., \& Wunder, S. 2008. Designing payments for environmental services in theory and practice: An overview of the issues. Ecolog. Econ. 65, 663-674.

ESRI. 2010. ArcGIS10. 380 New York Street, Redlands, CA 92373-8100: ESRI.

Fahey, B., \& Marden, M. 2006. Forestry Effects on Sediment Yield and Erosion. The Pakuratahi Land Use Study. A 12, 51-62.

Faustmann, M. 1995. Calculation of the value which forest land and immature stands possess for forestry. J. For. Econ. 1, 7-44.

Fisher, B., \& Turner, K. R. 2008. Ecosystem services: Classification for valuation. Biol. Conserv. 141, 1167-1169. doi:10.1016/j.biocon.2008.02.019

Fisher, B., Turner, R. K., \& Morling, P. 2009. Defining and classifying ecosystem services for decision making. Ecolog. Econ. 68, 643-653.

Fransen, P. J. B. 1998. Slips and sedimentation in mature plantation forest and pastoral hill country. Hawke's Bay, New Zealand: Logging Industry Research Organisation.

Fu, B. J., Su, C. H., Wei, Y. P., Willett, I., Lü, Y. H., \& Liu, G. H. 2011. Double counting in ecosystem services valuation: causes and countermeasures. Ecol. Res. 26, 1-14. doi:10.1007/s11284-010$0766-3$ 
Gluckman, P. 2011. Towards better use of information in policy formation (PMCSA discussion paper). Retrieved 18 February from the Chief Science Advisor to the Prime Minister's website: http://www.pmcsa.org.nz/wp-content/uploads/Towards-better-use-of-evidence-in-policyformation.pdf

Hicks, D. M., Gomez, B., \& Trustrum, N. A. 2000. Erosion thresholds and suspended sediment yields, Waipaoa River basin, New Zealand. Water Resour. Res. 36, 1129-1142.

Jansson, M. B. 1988. A global survey of sediment yield. Geogr. Ann. Ser. A. Phys. Geogr. 70, 81-98.

Jones, H., Clough, P. W. J., Hock, B., \& Phillips, C. 2008. Economic costs of hill country erosion and benefits of mitigation in New Zealand: Review and recommendation of approach. Wellington, New Zealand: Ministry for Agriculture and Forestry.

Kimberley, M. O., West, G., Dean, M. G., \& Knowles, R. L. 2005. The 300-Index - a volume productivity index for radiata pine. N. Z. J. For. 50, 13-18.

Krausse, M., Eastwood, C., \& Alexander, R. R. 2001. Muddied waters: Estimating the national economic cost of soil erosion and sedimentation in New Zealand. Palmerston North, New Zealand: Landcare Research.

Lynn, I., Manderson, A. K., Page, M. J., Harmsworth, G., Eyles, G., Douglas, G., MacKay, G., \& Newsome, P. 2009. Land use capability survey handbook - A New Zealand handbook for the classification of land. AgResearch, Hamilton; Landcare Research, Lincoln; GNS, Lower Hutt.

Maclaren, J. P. 2000. Trees in the greenhouse: The role of forestry in mitigating the enhanced greenhouse effect, Forest Research Bulletin (Vol. 219). Rotorua, New Zealand: Scion.

Maes, J., Egoh, B., Willemen, L., Liquete, C., Vihervaara, P., Schägner, J. P., Grizzetti, B., Drakou, E. G., Notte, A. L., Zulian, G., Bouraoui, F., Luisa Paracchini, M., Braat, L., \& Bidoglio, G. 2012. Mapping ecosystem services for policy support and decision making in the European Union. Ecosyst. Serv. 1, 31-39. doi:10.1016/j.ecoser.2012.06.004

MAF. 2011a. A guide to forestry in the emissions trading scheme. Wellington: Ministry of Agriculture and Forestry.

MAF. 2011b. Review of MAF afforestation schemes. In Forestry, M. о. A. a. (Ed.). Wellington: Ministry of Agriculture and Forestry.

MAF. Indicative New Zealand Radiata pine log prices by quarter. Retrieved Jun 202012 http://www.maf.govt.nz/news-resources/statistics-forecasting/forestry/indicative-newzealand-radiata-pine-log-prices-by.aspx 
Manley, B. 2012. Discount rates used for forest valuation - Results of 2011 survey. N. Z. J. For. 56, 2128.

Marden, M., Arnold, G., Gomez, B., \& Rowan, D. 2005. Pre- and post-reforestation gully development in Mangatu forest, East Coast, North Island, New Zealand. River Res. Appl. 21, 757-771.

Marden, M., \& Rowan, D. 1993. Protective value of vegetation on tertiary terrain before and during cyclone Bola, East Coast, North Island, New Zealand. N. Z. J. For. Sci., 255-263.

McGlone, M., Walker, S., Leathwick, J., \& Briggs, C. 2004. Predicted potential natural vegetation of New Zealand. (pp. Poster and electronic data produced by Manaaki Whenua Landcare Research, New Zealand).

Millennium Ecosystem Assessment. 2005. Ecosystems and human well-being: Synthesis. Island Press, Washington DC.

MPI. 2012. National Exotic Forest Description as of 1 April 2012. Wellington: Ministry for Primary Industries.

MPI. 2012. Situation and Outlook for Primary Industries 2012. Wellington: Ministry for Primary Industries.

Myers, N., Mittermeier, R. A., Mittermeier, C. G., da Fonseca, G. A. B., \& Kent, J. 2000. Biodiversity hotspots for conservation priorities. Nature $403,853-858$.

New Zealand Institute of Chartered Accountants. 2004. New Zealand Equivalent to International Accounting Standards, Property, plant and equipment (NZ IAS 16) (Vol. NZ 33.7): NZICA.

NIWA. Retrieved 21 July 2011 http://www.niwa.co.nz/our-science/freshwater/tools/rec

OANDA.http://www.oanda.com/currency/historical-rates/

OM Financial Ltd. Commtrade carbon. Retrieved www.commtrade.co.nz/

Palmer, D. J., Hock, B. K., Kimberley, M. O., Watt, M. S., Lowe, D. J., \& Payn, T. W. 2009b. Comparison of spatial prediction techniques for developing Pinus radiata productivity surfaces across New Zealand. For. Ecol. Manage. 258, 2046-2055.

Palmer, D. J., Hock, B. K., Lowe, D. J., Dunningham, A. G., \& Payn, T. W. 2009a. Developing nationalscale terrain attributes for New Zealand (TANZ). Forest Research Bulletin 232. 232. 
Palmer, D. J., Watt, M. S., Hock, B. K., Lowe, D. J., \& Payn, T. W. 2009b. A dynamic framework for spatial modelling Pinus radiata soil-water balance (SWatBal) across New Zealand. Forest Research Bulletin 234. 234.

Palmer, D. J., Watt, M. S., Kimberley, M. O., Hock, B. K., Payn, T. W., \& Lowe, D. J. 2010. Mapping and explaining the productivity of Pinus radiata in New Zealand. N. Z. J. For. 55, 15-21.

Pannell, D., J. 2008. Public benefits, private benefits, and policy mechanism choice for land-use change for environmental benefits. Land Econ. 84, 225-240.

Parra-López, C., Groot, J. C. J., Carmona-Torres, C., \& Rossing, W. A. H. 2009. An integrated approach for ex-ante evaluation of public policies for sustainable agriculture at landscape level. Land Use Policy 26, 1020-1030.

Pawson, S. M., Ecroyd, C. E., Seaton, R., Shaw, W. B., \& Brockerhoff, E. G. 2010. New Zealand's exotic plantation forests as habitats for threatened indigenous species. N. Z. J. Ecol. 34, 342-355.

Pearce, D. 2001. Valuing biodiversity: issues and overview Valuation of Biodiversity Benefits: Selected Studies. OECD, Paris.

Pimentel, D., Harvey, C., Resosudarmo, P., Sinclair, K., Kurz, D., McNair, M., Crist, S., Shpritz, L., Fitton, L., Saffouri, R., \& Blair, R. 1995. Environmental and economic costs of soil erosion and conservation benefits. Science 267, 1117-1123. doi:10.1126/science.267.5201.1117

Porou, T., Barnard, T., Fitzgerald, G., Moore, D., Barry, L., Garrett, L., \& Harrison, D. 2012. Benchmarking, scope assessment, and critical evaluation - Social, cultural and economic aspects of erosion for Ngati Porou and a desired state for the Waiapu catchment. Wellington: Ministry for Primary Industries.

PropertyIQ. Retrieved 21 March 2012 http://www.propertyiq.co.nz/about.html

Quine, C., Cahalan, C., Hester, A., Humphrey, J., Kirby, K., Moffat, A., \& Valatin, G. 2011. Woodlands. In Watson, R. \& Albon, S. (Eds.), UK National Ecosystem Assessment: Understanding nature's value to society (pp. 241-294). UNEP-WCMC, Cambridge.

Randall, A. 1983. Problem of Market Failure. Natural Res. J. 23, 131-148.

Reserve Bank of New Zealand. New Zealand inflation calculator. RetrievedReserve Bank of New Zealand. New Zealand inflation calculator. RetrievedReserve Bank of New Zealand. New Zealand inflation calculator. RetrievedReserve Bank of New Zealand. New Zealand inflation calculator. Retrieved 20 March 2012 http://www.rbnz.govt.nz/statistics/0135595.html 
Rhodes, D. 2001. Rehabilitation of deforested steep slopes on the East Coast of New Zealand's North Island. Unasylva (FAO).

Seaton, R., Holland, J. D., Minot, E. O., \& Springett, B. P. 2009. Breeding success of New Zealand falcons (Falco novaeseelandiae) in a pine plantation. N. Z. J. Ecol. 33, 32-39.

Statistics New Zealand. National Population Projections: 2011 (base)-2061. Retrieved 28th January 2012

http://www.stats.govt.nz/browse for stats/population/estimates and projections/NationalP opulationProjections HOTP2011.aspx

Statistics New Zealand. 2012. Global New Zealand - International trade, investment, and travel profile: Year ended June 2012. Wellington: Ministry of Foreing Affairs and Trade and Statistics New Zealand.

Thompson, S., Grüner, I., \& Gapare, N. 2003. New Zealand land cover database version 2. Illustrated guide to target classes. Ministry for the environment, Wellington.

Turner, J. A., West, G., Dungey, H., Wakelin, S., MacLaren, P., Adams, T., \& Silcock, P. 2008. Managing New Zealand planted forests for carbon. A review of selected scenarios and identification of knowledge gaps. Wellington, New Zealand: Ministry of Agriculture and Forestry.

UK National Ecosystem Assessment, 2011. The UK National Ecosystem Assessment: Synthesis of the Key Findings. UNEP-WCMC, Cambridge.

United States Environmental Protection Agency. 2005. Greenhouse gas mitigation potential in U.S. forestry and agriculture. In Office of Atmospheric Programs (Ed.). Washinton DC: USEPA.

Watt, M. S., Palmer, D. J., \& Hock, B. 2010. Spatial description of potential areas suitable for afforestation within New Zealand and quantification of their productivity under Pinus Radiata. Scion.

Wätzold, F., \& Drechsler, M. 2005. Spatially Uniform versus Spatially Heterogeneous Compensation Payments for Biodiversity-Enhancing Land-Use Measures. Environ. Resour. Econ. 31, 73-93. doi:10.1007/s10640-004-6979-6

Yao, R. 2012. The non-market value of biodiversity enhancement in New Zealand's planted forests: PhD Thesis. Unpublished PhD thesis, University of Waikato, Hamilton, New Zealand.

Yao, R., \& Kaval, P. 2010. Valuing biodiversity enhancement in New Zealand. Int. J. Ecol. Econ. Stat. $16,26-42$. 


\section{$8 \quad$ Footnotes}

${ }^{1}$ Meshblocks ( 1 ha in area) were used as the identifying area for land values instead of primary parcels. However not all primary parcels within each meshblock were identified, meaning that in some cases the dollar value per hectare may have been underestimated. Also some meshblocks where forests were located returned no data and therefore these forests have been excluded from the final economic calculation.

${ }^{2}$ Further modelling details are available from the authors on request.

${ }^{3}$ Ministry of Agriculture and Forestry (MAF) changed its name to Ministry for Primary Industries (MPI) in 2012.

${ }^{4}$ https://www.commtrade.co.nz/

${ }^{5}$ The East Coast Forestry Project has been implemented which provides payments to landowners afforesting on erosion-prone lands on the East Coast Region.

${ }^{6}$ Carbon is calculated using an annuity rather than actual estimates of carbon sequestered and emitted over time. The former was used for ease of evaluating the economics of carbon within the GIS, and that the two accounting approaches lead to similar, though not the same estimates of NPV of carbon credit revenues. The former provides a lower estimate NPV than the latter so it is more conservative. 